\title{
Hydrothermal synthesis and structural characterization of ammonium ion-templated lanthanide(III) carboxylate-phosphonates
}

\author{
Ayi A. Ayi ${ }^{1,2 *}$, Tiffany L. Kinnibrugh ${ }^{2}$ and Abraham Clearfield ${ }^{2 *}$ \\ ${ }^{1}$ Department of Pure and Applied Chemistry, University of Calabar, Calabar, Nigeria \\ 2 Department of Chemistry, Texas A\&M University, College Station, TX, USA
}

Edited by:

Zifeng Yan, China University of

Petroleum, China

Reviewed by:

David J. Harding, Walailak

University, Thailand

Chaoxian Xiao, lowa State

University, USA

\section{*Correspondence:}

Ayi A. Ayi, Department of Pure and Applied Chemistry, University of Calabar, P.M.B. 1115, Calabar

540242, Nigeria

e-mail: ayiayi72@gmail.com;

Abraham Clearfield, Department of

Chemistry, Texas A\&M University,

College Station, TX 77842-3255,

USA

e-mail:clearfield@

mail.chem.tamu.edu
Using $\mathrm{N}$-(phosphonomethyl) iminodiacetic acid ( $\left.\mathrm{H}_{4} \mathrm{PMIDA}\right)$, as a complexing agent, two new complexes, $\left(\mathrm{NH}_{4}\right) \mathrm{La}(\mathrm{PMIDA})\left(\mathrm{H}_{2} \mathrm{O}\right) \bullet \mathrm{H}_{2} \mathrm{O}, \mathbf{1}$ and $\left(\mathrm{NH}_{4}\right) \mathrm{Yb}(\mathrm{PMIDA}), \mathbf{2}$ have been synthesized hydrothermally. In both compounds, the metal ions are trapped by a three five-membered chelate rings by the chelating PMIDA anions giving a tricapped trigonal prismatic $\mathrm{LaO}_{8} \mathrm{~N}$ and monocapped trigonal prismatic $\mathrm{YbO}_{6} \mathrm{~N}$ geometries for $\mathbf{1}$ and $\mathbf{2}$, respectively. The structure of $\mathbf{1}$ consists of $\mathrm{La}(\mathrm{PMIDA})\left(\mathrm{H}_{2} \mathrm{O}\right)$ chelating units, linked together by the phosphonate oxygen atoms $\mathrm{O} 1$ and $\mathrm{O} 3$ to form a chain along the $c$-axis. The chains are then connected together by the bridging phosphonate oxygen $\mathrm{O} 2$ to form a 2D layered structure with alternating 4- and 8-membered apertures. The structure of $\mathbf{2}$ consists $\mathrm{Yb}$ (PMIDA) chelating units, which are connected by alternating bridging carboxylate and phosphonate groups along the [010] direction forming chains with a corrugated pattern. The third phosphonate oxygen bridges the chains together along the [001] direction to build the two-dimensional layer with 4- and 6-membered apertures in the bc-plane. Under excitation of $330 \mathrm{~nm}$, compound 2 shows a broad emission band at $\lambda_{\max }=460 \mathrm{~nm}$. This emission is essentially in the blue luminescent region, which corresponds to ligand centered fluorescence.

Keywords: hydrothermal synthesis, carboxylate-phosphonate hybrid material, metal organophosphonate frameworks, aminopolyacid ligand, flexible coordination

\section{INTRODUCTION}

The complexing ability of phosphonic acids have been extensively exploited in the design and synthesis of metalorganophosphonate-type metal organic frameworks (MOFs) with the formation of new and interesting compounds (Clearfield, 1988; Gagnon et al., 2012). The great interest in metal phosphonates is not only for their many unusual structural features, but also for their potential applications in different fields including adsorption, separation, gas storage, catalysis, photoluminescence, and drug delivery (Zhang and Clearfield, 1997; Sharma and Clearfield, 2000; Lukes et al., 2001; Bazaga-García et al., 2014; Liu et al., 2014). Recently, we have prepared and structurally characterized a molybdenumdiphosphonate coordination network, and shown that it can undergo reversible dehydration, which occurs with a structural change. The dehydrated material shows size selective adsorption of alcohols, adsorbing methanol but not ethanol (Ayi et al., 2013). Furthermore, we have reported crystal structures of two anionic 3D frameworks using 1,3,5-benzenetriphosphonic acid (BTP) with small amines as counter cations,

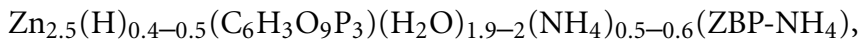
and $\mathrm{Zn}_{2.5}(\mathrm{H})_{0.75}\left(\mathrm{C}_{6} \mathrm{H}_{3} \mathrm{O}_{9} \mathrm{P}_{3}\right)\left(\mathrm{H}_{2} \mathrm{O}\right)_{2}\left(\mathrm{CH}_{3} \mathrm{NH}_{3}\right)_{0.25}$ (ZBP$\mathrm{CH}_{3} \mathrm{NH}_{3}$ ), resulting from the hydrothermal synthesis using $\mathrm{Zn}$ (II) cations and BTP (Kinnibrugh et al., 2013). The compounds were found to exhibit a reversible dehydration process with two phase transitions resulting in a loss of volume. Research has shown that poorly crystalline metal phosphonates are common and a combination of phosphonic acids with additional carboxylic functional groups gives variety of interesting crystalline compounds (Poojary et al., 1994). The construction of multi-dimensional coordination polymers with carboxylateand/ or phosphonate-based organic linkers has been the focus of many research groups (Galdecka et al., 2000; Paz et al., 2005; Ananias et al., 2006; Soares-Santos et al., 2006; Bao et al., 2007; Cunha-Silva et al., 2007; Girginova et al., 2007; Paz and Klinowski, 2007, 2008; Tang et al., 2007; Chelebaeva et al., 2008; Ferreira et al., 2008; Rodrigues et al., 2008; Shi et al., 2008). The use of highly flexible and/or aromatic-based organic moieties in conjunction with two or more chelating phosphonate groups has enabled the isolation of a number of structures in recent times (Serpaggi and Ferey, 1998; Evans et al., 2001; Groves et al., 2005, 2006; Ying and Mao, 2006). In the last two decades, we and others have investigated the use of a versatile chelating organic ligand: $N$-(phosphonomethyl) iminodiacetic acid $\left(\mathrm{H}_{4} \mathrm{PMIDA}\right)$ in the synthesis of metal carboxylate-phosphonate hybrid compounds (Zhang et al., 1996, 1998; Gutschke et al., 1999; Mao and Clearfield, 2002; Almeida Paz et al., 2004; Shi et al., 2005, 2006; Tang et al., 2006a). Using $\mathrm{H}_{4} \mathrm{PMIDA}$, as a complexing 
agent in the presence of phosphoric acid, a mixed phosphate phosphonate layered zirconium compound was obtained by our group (Zhang et al., 1996). A linear chain compound was isolated when the reaction was carried out in the absence of phosphoric acid (Zhang et al., 1998). In both cases, the iminodiacetic moieties are only involved in hydrogen bonding, and are available for further metal complexing. An antiferromagnet $\mathrm{K}_{2} \mathrm{Co}$ (PMIDA) $\} \cdot \mathrm{xH}_{2} \mathrm{O}$, whose crystal structure features a hexameric ring in the chair conformation was isolated by Wood and co-workers through the interaction of the salt of cobalt with $\mathrm{H}_{4}$ PMIDA as ligand (Gutschke et al., 1999). Also with $\mathrm{H}_{4}$ PMIDA ligand, we reported two divalent metal carboxylate-phosphonate hybrid compounds of composition $\left[\mathrm{Co}_{2}(\mathrm{PMIDA})\left(\mathrm{H}_{2} \mathrm{O}\right)_{5}\right] \cdot \mathrm{H}_{2} \mathrm{O}$ and $\left[\mathrm{Zn}_{2}\right.$ (PMIDA) $\left.\left(\mathrm{CH}_{3} \mathrm{CO}_{2} \mathrm{H}\right)\right] \cdot 2 \mathrm{H}_{2} \mathrm{O}$. The structure of cobalt compound contains double layers of $\mathrm{Co}$ (II)carboxylate interconnected by layers of $\mathrm{Co}$ (II)phosphonate, while the crystal structure of zinc compound features a zinc carboxylate-phosphonate hybrid layer along the [202] plane (Mao and Clearfield, 2002). Mao and co-workers isolated isostructural lanthanide carboxyphosphonates $\mathrm{Ln}(\mathrm{HPMIDA})\left(\mathrm{H}_{2} \mathrm{O}\right)_{2} \bullet 3 \mathrm{H}_{2} \mathrm{O}(\mathrm{Ln}=\mathrm{Gd}, \mathrm{Tb}$, Dy, $\mathrm{Y}, \mathrm{Er}, \mathrm{Yb}, \mathrm{Lu})$, based on $\mathrm{H}_{4} \mathrm{PMIDA}$ anion, which exhibit a three-dimensional (3D) open-framework structures with helical tunnels (Tang et al., 2006a). Several research groups have constructed multi-dimensional frameworks by using $\left[\mathrm{V}_{2} \mathrm{O}_{2}(\mathrm{PMIDA})_{2}\right]^{4-}$ anionic unit, as well as a one-dimensional coordination polymer containing $\mathrm{H}_{4}$ PMIDA residues and $\mathrm{Fe}^{2+}$ centers (Almeida Paz et al., 2004; Shi et al., 2005, 2006). In continuation of our investigation of the flexible coordinating properties of $\mathrm{H}_{4} \mathrm{PMIDA}$, as a ligand, we extended our research to the lanthanides system. The design and syntheses of porous lanthanide phosphonates are attractive in developing new materials with multifunctions (Song and Mao, 2005; Ying and Mao, 2006; Liu et al., 2007; Mao, 2007). The successful synthesis of the first open-framework lanthanide carboxyphosphonate $\mathrm{Pr}_{4}\left(\mathrm{H}_{2} \mathrm{O}\right)_{7}\left(\mathrm{O}_{3} \mathrm{PCH}_{2} \mathrm{NC}_{5} \mathrm{H}_{9} \mathrm{COO}\right)_{4}\left(\mathrm{H}_{2} \mathrm{O}\right)$, opened the way for a number of other lanthanide hybrid solids to be isolated (Massiot et al., 1997; Legendziewicz et al., 1998; Serre et al., 2004; Bauer et al., 2006; Tang et al., 2006a,b; Huang et al., 2007; Zhou et al., 2010). For example, using lanthanide chlorides and $\mathrm{N}$-(carboxymethyl)iminodi(methylphosphonic acid $)\left(\mathrm{H}_{5} \mathrm{cmp}\right)$ a series of layered $\left[\mathrm{Ln}\left(\mathrm{H}_{2} \mathrm{cmp}\right)\left(\mathrm{H}_{2} \mathrm{O}\right)\right]$ materials [where $\mathrm{Ln}^{3+}=\mathrm{Y}^{3+}, \mathrm{La}^{3+}, \mathrm{Pr}^{3+}, \mathrm{Nd}^{3+}, \mathrm{Sm}^{3+}, \mathrm{Eu}^{3+}, \mathrm{Gd}^{3+}$, $\mathrm{Tb}^{3+}, \mathrm{Dy}^{3+}, \mathrm{Ho}^{3+}$, and $\left.\mathrm{Er}^{3+}\right]$, and the mixed-lanthanide $\left[\left(\mathrm{Gd}_{0.95} \mathrm{Eu}_{0.05}\right)\left(\mathrm{H}_{2} \mathrm{cmp}\right)\left(\mathrm{H}_{2} \mathrm{O}\right)\right]$ material, have been successfully isolated from hydrothermal synthesis as phase-pure micro-crystalline compounds, (Cunha-Silva et al., 2009) and found to be supramolecular polymorphs of the compound that was reported by Mao and co-workers (Massiot et al., 1997; Bauer et al., 2006; Tang et al., 2006b; Zhou et al., 2010). Using phoshonoacetic acid as a complexing agent, a linear chain aluminum(III)carboxyphosphonate with ammonium ion as counter cation has been reported (Ayi et al., 2011). The ammonium cations were generated in-situ from the partial decomposition of urea. By employing a similar technique with the rare earth elements, we have been able to isolate two new materials $\left(\mathrm{NH}_{4}\right)\left[\mathrm{La}(\mathrm{PMIDA})\left(\mathrm{H}_{2} \mathrm{O}\right)\right] \bullet \mathrm{H}_{2} \mathrm{O}$, 1, and $\left(\mathrm{NH}_{4}\right)[\mathrm{Yb}(\mathrm{PMIDA})], 2$, exhibiting $2 \mathrm{D}$ structures.
This paper reports the synthesis and characterization of these two lanthanide(III)carboxyphosphonates.

\section{EXPERIMENTAL \\ SYNTHESIS AND CHEMICAL ANALYSIS}

The two compounds $\left(\mathrm{NH}_{4} \mathrm{La}(\mathrm{PMIDA})\left(\mathrm{H}_{2} \mathrm{O}\right) \bullet \mathrm{H}_{2} \mathrm{O}, \quad \mathbf{1}\right.$ and $\left(\mathrm{NH}_{4}\right) \mathrm{Yb}$ (PMIDA), 2 were hydrothermally synthesized (autogenous pressure for 6 days) at $160^{\circ} \mathrm{C}$ from a mixture of lanthanum chloride heptahydrate $\mathrm{LaCl}_{3} .7 \mathrm{H}_{2} \mathrm{O}$ (Aldrich, 98\%) for 1, ytterbium oxide $\mathrm{Yb}_{2} \mathrm{O}_{3}$ for 2, $\mathrm{HCl}$ (Fisher Scientific), N(phoshonomethyl)iminodiacetic acid, $\mathrm{H}_{4} \mathrm{PMIDA}($ Aldrich, 95\%), potassium acetate (Fisher Scientific), urea (EM Science), and $\mathrm{H}_{2} \mathrm{O}$ /dioxane in the molar ratio 1:2:1: 2: 2.2: 80/10. In a typical synthesis of $1, \mathrm{LaCl}_{3} \cdot 7 \mathrm{H}_{2} \mathrm{O}(0.557 \mathrm{~g}, 1.5 \mathrm{mmol})$ was dispersed in $2 \mathrm{ml}$ of water followed by the addition of $0.26 \mathrm{ml} \mathrm{HCl}$ and $0.84 \mathrm{ml} 1,4$-dioxane. To this mixture was added $\mathrm{H}_{4} \mathrm{PMIDA}(0.34 \mathrm{~g}$, $1.5 \mathrm{mmol})$, urea $(0.20 \mathrm{~g}, 3.3 \mathrm{mmol})$ and potassium acetate $(0.10$ $\mathrm{g}, 1.0 \mathrm{mmol})$. The resulting suspension with a $\mathrm{pH}$ of 1 was sealed in a Teflon-lined steel autoclave and heated at $160^{\circ} \mathrm{C}$ for 6 days. The product, a crop of colorless plate-like crystals was filtered and washed with distilled water and dried at ambient temperature. Compound 2 was obtained similarly from the composition $\mathrm{Yb}_{2} \mathrm{O}_{3}(0.28 \mathrm{~g}, 1.5 \mathrm{mmol}) ; 0.26 \mathrm{ml} \mathrm{HCl} ; 2 \mathrm{ml} \mathrm{H}{ }_{2} \mathrm{O}$; $0.84 \mathrm{ml}$ Dioxane; $\mathrm{H}_{4} \mathrm{PMIDA}(0.34 \mathrm{~g}, 1.5 \mathrm{mmol})$; and Urea $(0.20 \mathrm{~g}$, $3.3 \mathrm{mmol}$ ). The final $\mathrm{pH}$ was 3.5 and 2 for compounds 1 and 2, respectively. Initial characterization was carried out by powder $\mathrm{X}$-ray diffraction (PXRD), inductively coupled plasma-atomic

Table 1 | Crystal data and structure refinement for 1 and 2.

\begin{tabular}{|c|c|c|}
\hline & 1 & 2 \\
\hline Formula & $\mathrm{C}_{5} \mathrm{H}_{14} \mathrm{~N}_{2} \mathrm{O}_{9} \mathrm{P}$ La & $\mathrm{C}_{5} \mathrm{H}_{10} \mathrm{~N}_{2} \mathrm{O}_{7} \mathrm{P} \mathrm{Yb}$ \\
\hline Formula mass & 416.06 & 414.16 \\
\hline Crystal system & Monoclinic & Monoclinic \\
\hline Space group & $\mathrm{P} 2{ }_{1} / \mathrm{c}$ & $\mathrm{P} 2{ }_{1} / \mathrm{c}$ \\
\hline$a(\AA ̊)$ & $7.059(4)$ & $9.181(3)$ \\
\hline$b(\AA)$ & $23.577(12)$ & $8.889(3)$ \\
\hline$c(\AA)$ & $6.871(3) \AA$ & $12.827(4)$ \\
\hline$\beta\left({ }^{\circ}\right)$ & $94.292(6)^{\circ}$ & $101.414(3)$ \\
\hline$V\left(\AA^{3}\right)$ & $1140.4(10)$ & $1026.0(5)$ \\
\hline$z$ & 4 & 4 \\
\hline$\rho_{c}\left(\mathrm{Mg} \mathrm{m}^{-3}\right)$ & 2.423 & 2.681 \\
\hline$\mu\left(\mathrm{Mo} \mathrm{K}_{\alpha}\right)\left(\mathrm{mm}^{-1}\right)$ & 3.931 & 9.294 \\
\hline$F(000)$ & 808 & 780 \\
\hline Reflections collected & 7029 & 8719 \\
\hline Independent reflections & $\begin{array}{l}2460[R(\text { int })= \\
0.1268]\end{array}$ & $\begin{array}{l}2454[R \text { (int) }= \\
0.0718]\end{array}$ \\
\hline GOF on $F^{2}$ & 1.015 & 1.028 \\
\hline Final $R$ indices $[I>2 \sigma(I)]^{a}$ & $\begin{array}{l}R_{1}=0.0688 \\
w R_{2}=0.1361 \\
R 1=0.1483 \\
w R 2=0.1680\end{array}$ & $\begin{array}{l}R_{1}=0.0321 \\
w R_{2}=0.0880 \\
R_{1}=0.0363 \\
w R_{2}=0.0928\end{array}$ \\
\hline Final $R$ indices (All data) & 1.849 & 1.698 \\
\hline$(\Delta \rho)_{\max },(\Delta \rho)_{\min }\left(\mathrm{e} . \AA^{-3}\right)$ & -2.057 & -2.685 \\
\hline
\end{tabular}

${ }^{a} R_{1}=\Sigma|| F_{o}|-| F_{c}|| \Sigma\left|F_{o}\right| \cdot w R_{2}=\left[\Sigma w\left(F_{o}^{2}-F_{c}^{2}\right)^{2} / \Sigma w\left(F_{o}^{2}\right) 2\right]^{1 / 2}$ 
emission spectroscopy (ICP-AES), thermogravimetric analysis (TGA), elemental CHN analysis, and IR spectroscopy. The PXRD patterns of 1 and $\mathbf{2}$ compared with their simulated patterns from single crystal analyses are presented in Figure S1. ICP-AES gave a Ln: $P$ ratio of 1: 1 in agreement with the formula. $\mathrm{C}_{5} \mathrm{H}_{14} \mathrm{~N}_{2} \mathrm{O}_{9} \mathrm{PLa}$ (416.06) 1, (based on single-crystal data): calcd. La 33.55, P 7.48, C 14.43, H 3.39, N 6.73; found La 34.54, P 7.32, C 14.21, $\mathrm{H}$ 3.35, N 6.49; $\mathrm{C}_{5} \mathrm{H}_{10} \mathrm{~N}_{2} \mathrm{O}_{7} \mathrm{PYb}$ (414.16) 2, (based on singlecrystal data): calcd. Yb 41.77, P 7.48, C 14.51, H 2.43, N 6.76, found $\mathrm{Yb}$ 40.80, $\mathrm{P}$ 7.18, $\mathrm{C}$ 14.52, $\mathrm{H}: 2.37, \mathrm{~N}$ 6.63. TGA data (mass losses), 1: $43-197^{\circ} \mathrm{C} 4.72 \%$ (DTG peak at $62^{\circ} \mathrm{C}$ ); $231-$ $393^{\circ} \mathrm{C} 6.89 \%$ (DTG peaks at 267,294 , and $326^{\circ} \mathrm{C}$ ); $436-893^{\circ} \mathrm{C}$ $41.2 \%$ (DTG peaks at $638,755,794$, and $845^{\circ} \mathrm{C}$. $2: 260-460^{\circ} \mathrm{C}$ $28.82 \%$ (DTG peak at $362^{\circ} \mathrm{C}$ ); $860-958^{\circ} \mathrm{C} 35.9 \%$ (DTG peak at $\left.958^{\circ} \mathrm{C}\right)$; Selected ATR-FTIR data $\left(\mathrm{cm}^{-1}\right), \mathbf{1}: \mathrm{v}(\mathrm{O}-\mathrm{H}$ and $\mathrm{N}-\mathrm{H}$ involved in hydrogen bonding interactions) $=3440-3000 \mathrm{~s}$, (very broad), $v\left(\mathrm{C}-\mathrm{H}\right.$ in $\left.-\mathrm{CH}_{2-}\right)=2981 \mathrm{w}, v_{\text {asym }}\left(\mathrm{CO}_{2}^{-}\right)=1558$ vs. $v_{\text {sym }}\left(\mathrm{CO}_{2}^{-}\right)=1399 \mathrm{~s}, \delta(\mathrm{O}-\mathrm{H} . . \mathrm{O})=1338 \mathrm{~m}, v(\mathrm{C}-\mathrm{O})=1247 \mathrm{~m}$, $v(\mathrm{C}-\mathrm{N}) 1117, v_{\text {asym }}(\mathrm{P}-\mathrm{O})=1018 \mathrm{~s}, v_{\text {sym }}(\mathrm{P}-\mathrm{O})=981 \mathrm{~s}, \mathrm{v}(\mathrm{P}-\mathrm{C})=$ $787 \mathrm{~m}$. 2: $v\left(\mathrm{C}-\mathrm{H}\right.$ in $\left.-\mathrm{CH}_{2-}^{-}\right)=2948 \mathrm{w}, v_{\text {asym }}\left(\mathrm{CO}_{2}^{-}\right)=1593$ vs. $v_{\text {sym }}\left(\mathrm{CO}_{2}^{-}\right)=1405 \mathrm{~s}, 1384 \mathrm{~s}, \delta\left(-\mathrm{CH}_{2^{-}}\right)=1448 \mathrm{~m}, \mathrm{v}(\mathrm{C}-\mathrm{O})=$ $1341 \mathrm{~m}, 1333 \mathrm{sh}, 1257 \mathrm{w}, 1232 \mathrm{~m}, \delta(\mathrm{C}-\mathrm{C}-\mathrm{N}$, amines $)=1154 \mathrm{~m}$, $v(\mathrm{C}-\mathrm{N})=1122 \mathrm{w}, v_{\text {asym }}(\mathrm{P}-\mathrm{O})=1084$ vs. $v_{\text {sym }}(\mathrm{P}-\mathrm{O})=1020 \mathrm{~s}$, $1006 \mathrm{~m}, 974 \mathrm{w}, \mathrm{v}(\mathrm{P}-\mathrm{C})=786 \mathrm{~s}, 713 \mathrm{~s}$.

\section{INSTRUMENTATION}

A PXRD pattern was recorded at ambient temperature on a Bruker D8 Advance diffractometer $\left(\mathrm{CuK}_{\alpha}\right.$ radiation $\lambda=1.54056$ $\AA$ ) fitted with Lynx EYE detector. Data were collected using a flat plate sample holder. Intensity data were collected by the continuous counting method (step $0.03^{\circ}$ and time $3 \mathrm{~s}$ ) in the range $5-50^{\circ} 2 \theta$. Excel and Origin 7 were used to analyse the data. Elemental analysis $(\mathrm{C}, \mathrm{H}$, and $\mathrm{N})$ was performed by Atlantic Microlab, Inc. For $\mathrm{La} / \mathrm{P}$ and $\mathrm{Yb} / \mathrm{P}$ ratios, samples were digested in conc $\mathrm{HNO}_{3}$ and Anderson Analytical determined the relative amounts by ICP-AES. Thermal analysis was carried out with a Rigaku Thermoflex 8110 unit at a heating rate of $5^{\circ} \mathrm{C} / \mathrm{min}$ under nitrogen atmosphere from room temperature to $1000^{\circ} \mathrm{C}$. Attenuated total reflection Fourier transform infrared (ATRFTIR) spectra $\left(4000-400 \mathrm{~cm}^{-1}\right)$ were recorded with a PerkinElmer 883 spectrometer.

\section{CRYSTAL STRUCTURE DETERMINATION}

Single crystal data were collected on a Bruker-AXS Apex II CCD $\mathrm{X}$-ray diffractometer $(\mathrm{MoK} \alpha$ radiation, $\lambda=0.71073 \AA$ ) operating at $110 \mathrm{~K}$. The data were reduced using SAINTPLUS, (Bruker, 2005) and an empirical absorption correction was applied using the SADABS program (Sheldrick, 2008b). The structures were solved by direct methods and refined by the full-matrix leastsquares technique against $\mathrm{F}^{2}$ with the anisotropic displacement parameters for all non-hydrogen atoms using SHELXL-2008 (Sheldrick, 2008a). All hydrogen atoms except those for the water molecules and ammonium, were added in idealized positions and refined using a riding model with $U_{i s o}=n U_{e q}$ for carbon atoms connected to the relevant $\mathrm{H}$-atom where $n=1.5$ for methyl and $n=1.2$ for other $\mathrm{H}$-atoms. The hydrogen atoms for the water molecules and ammonium ions in both compounds were located from difference Fourier maps and were refined using a riding mode. Anisotropic displacement parameters were established for all non-hydrogen atoms. Selected data collection and refinement parameters are summarized in Table 1. More details on crystallographic studies as well as atom displacement parameters are given in the Supporting Information (CCDC 847459) and (CCDC 847460) for compounds 1 and 2, respectively).

\section{RESULTS AND DISCUSSION}

The hydrothermal treatment of $\mathrm{H}_{4}$ PMIDA with the lanthanides $(\mathrm{Ln}=\mathrm{La}, 1 ; \mathrm{Yb}, 2)$ in the presence of $\mathrm{HCl}$-urea afforded two new lanthanide(III)carboxylate-phosphonates, namely $\left(\mathrm{NH}_{4}\right)\left[\mathrm{La}(\mathrm{PMIDA})\left(\mathrm{H}_{2} \mathrm{O}\right)\right] \bullet \mathrm{H}_{2} \mathrm{O}, \mathbf{1}$, and $\left(\mathrm{NH}_{4}\right)[\mathrm{Yb}(\mathrm{PMIDA})], 2$ incorporating ammonium ions to balance the anionic framework $[\operatorname{Ln}(\mathrm{PMIDA})]^{-}$charge of -1 . The ammonium cations are generated in-situ from the partial decomposition of urea and are crucial in the reaction as structure directors. The $\mathrm{pH}$ of the reaction mixtures significantly influences the formation of the product. The initial $\mathrm{pH}$ for both compounds was 1.0. Whereas a final $\mathrm{pH}$ in the range of 3.5-4.0 favors the formation of compound 1, a pH of 2.0 was found to favor compound 2 . The addition of urea and potassium acetate in the reaction vessel were needed to control the $\mathrm{pH}$ of the reaction media and to yield crystalline samples as direct addition of ammonia solution to the synthetic mixture could not lead to the formation of the products. The two compounds exhibit two-dimensional layered structures with distinct features.

The asymmetric unit of $\mathbf{1}$ consists of one crystallographically independent Lanthanum(III) ion, a PMIDA ${ }^{4-}$ anion,

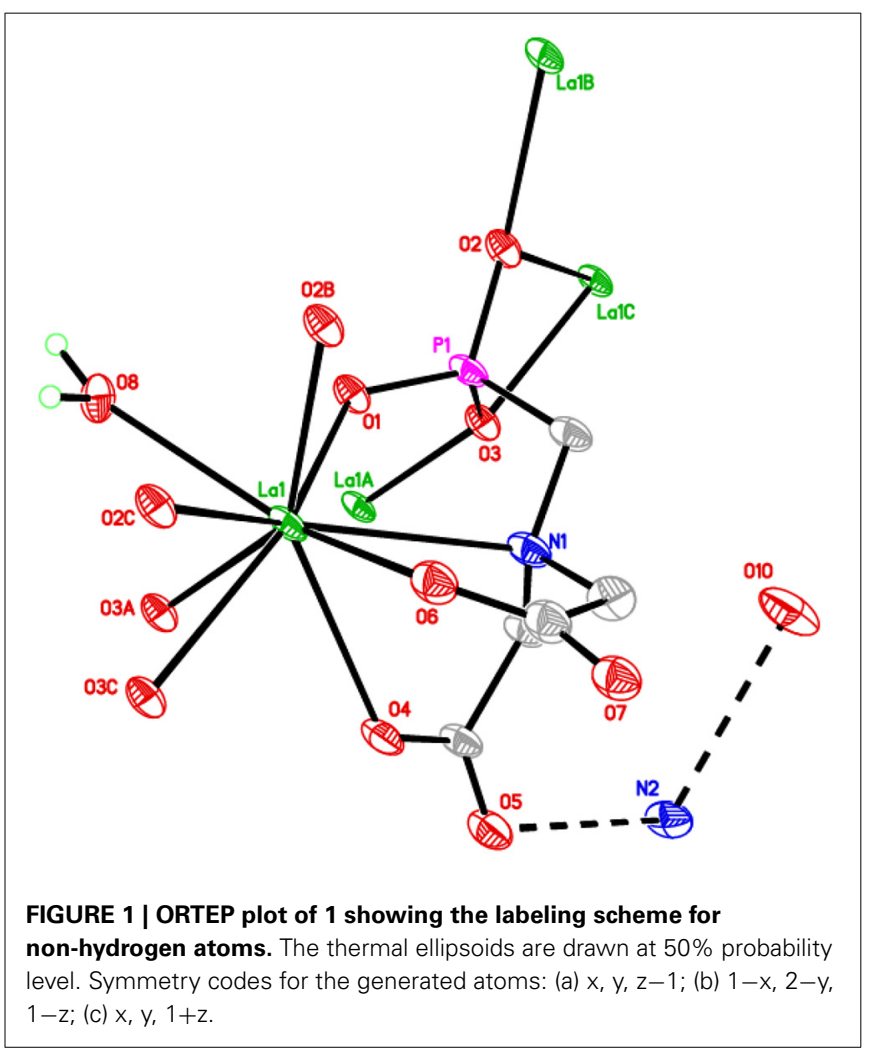


aqua ligand, a lattice water and an ammonium ion for charge balancing. The PMIDA ${ }^{4-}$ anion coordinates to the central La ion in a tetradentate fashion via one oxygen atom from each of the carboxylates (O4 and O6), one oxygen atom from the phosphonate $(\mathrm{O} 1)$, and a nitrogen atom from the amino group (N1). This forms three five-membered chelation rings. The one independent $\mathrm{La}(\mathrm{III})$ ion is nine-coordinate and to fulfill the coordination, three other PMIDA anions coordinates to the metal center through the phosphonate oxygen atoms $(\mathrm{O} 3 \mathrm{~A}, \mathrm{O} 2 \mathrm{~B}, \mathrm{O} 3 \mathrm{C}$, and $02 \mathrm{C})$ as shown in Figure 1. The geometry about the central atom is trigonal prismatic tricapped by $\mathrm{N}(1)$ and $\mathrm{O}(8)$. The interatomic distances are well defined. La-O distances are within the 2.458(9)-2.732(9) $\AA$ range $\left[\mathrm{La}-\mathrm{O}_{\mathrm{av}}=2.568 \AA\right]$ and La-N distance is $2.821(12) \AA$, while the $\mathrm{C}-\mathrm{O}$ and $\mathrm{P}-\mathrm{O}$ distances are within the 1.248(16)-1.271(16), and $1.508(9)-1.543(10) \AA$ ranges, respectively and are indicative of complete deprotonation of both the carboxylate and phosphonate groups. The longest $\mathrm{P}-\mathrm{O}$ distance belongs to the $\mu^{2}$ - bridging oxygen atoms. The P-C distance is 1.791(14) $\AA$. These distances are in good agreement with similar compounds in the literature (Legendziewicz et al., 1998; Serre et al., 2004; Song and Mao, 2005; Tang et al., 2006a; Ying and Mao, 2006; Huang et al., 2007; Liu et al., 2007; Mao, 2007).

The PMIDA ${ }^{4-}$ anion is a polydentate ligand, which chelates with a lanthanum(III) ion in a tetradentate fashion and bridges three other lanthanum ions using the phosphonate oxygen atoms. The phosphorus atom $\mathrm{P}(1)$ on the tetradentate ligand coordinating to $\mathrm{La}(1)$ via $\mathrm{O} 1$, forms multiple bonds to three equivalent lanthanum atoms $[\mathrm{La}(1 \mathrm{~A}), \mathrm{La}(1 \mathrm{~B})$, and $\mathrm{La}(1 \mathrm{C})]$ through the remaining two oxygen atoms $\mathrm{O} 2$ and $\mathrm{O} 3$ giving rise to a [122] connectivity mode (Massiot et al., 1997; Bauer et al., 2006; Tang et al., 2006a,b; Zhou et al., 2010). While the phosphonate oxygen $\mathrm{O} 2$ and $\mathrm{O} 3$ both chelate with the $\mathrm{La}(1 \mathrm{~A})$ center, $\mathrm{O} 3$ also bridges with $\mathrm{La}(1 \mathrm{~B})$ to form a chain propagating along the [001] direction as shown in Figure 2. Within the chain, the La... La distances over $\mu_{3}-\mathrm{O} 3$ and $\mathrm{O} 1-\mathrm{P} 1-\mathrm{O} 3$ bridges are $4.227(2)$ and $6.871(3)$ $\AA$, respectively. The chains are then connected together by the

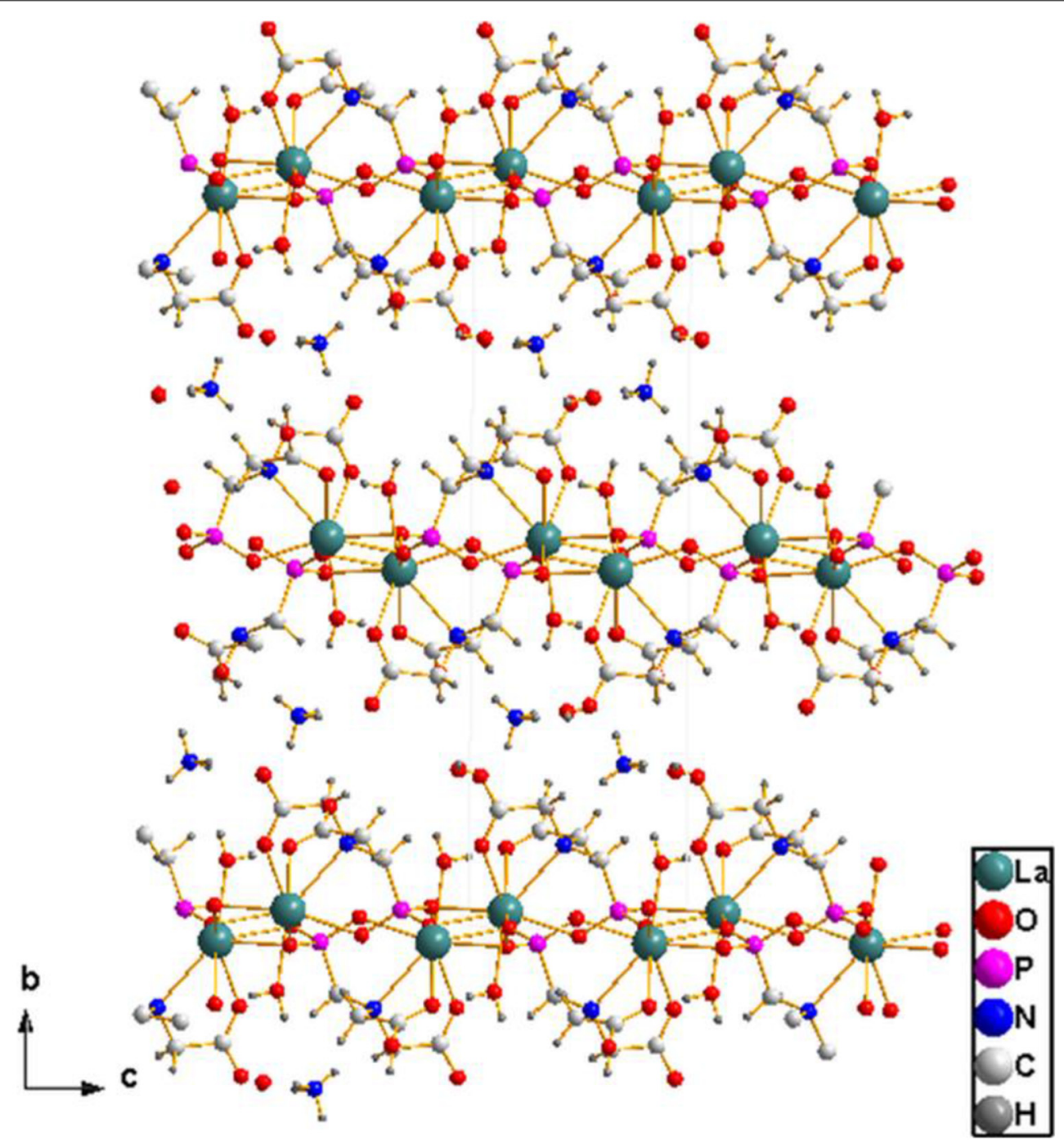

FIGURE 2 | View of compound 1 along [001] direction showing the chain structure. 


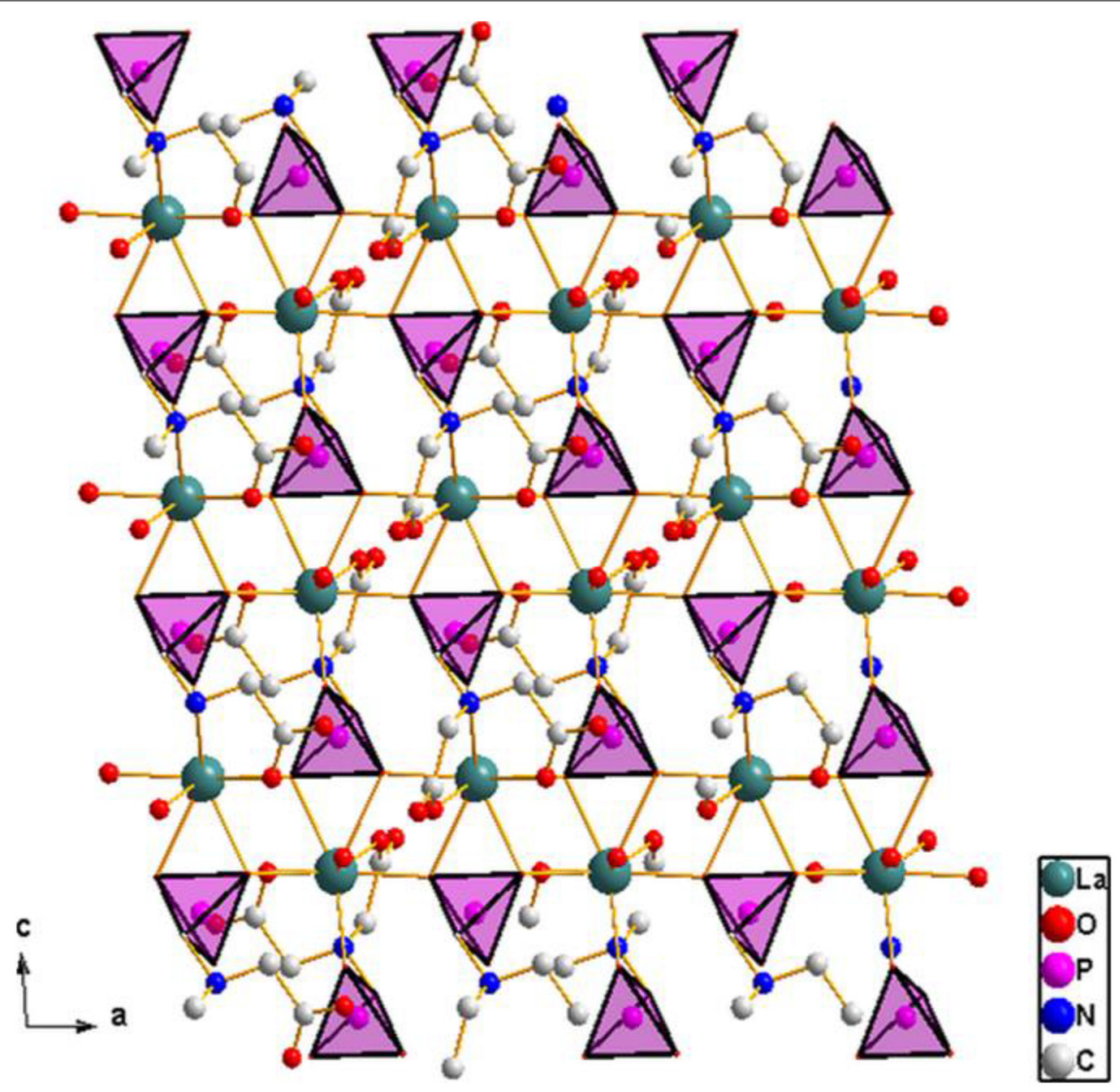

FIGURE 3 | Structure of 1 viewed along $\boldsymbol{b}$-axis showing the connectivity that gives rise to 2D layer. The lattic water and ammonium ions are ommitted for clarity.

bridging phosphonate oxygen $\mathrm{O} 2$ to form a 2D layered structure with alternating 4- and 8-membered rings as shown in Figure 3. Each of the two carboxylate oxygen coordinates to the $\mathrm{La}$ (III) center in a monodentate fashion. The two non-coordinating carboxylate oxygen atoms $[\mathrm{O} 5, \mathrm{O} 7]$ point into the interlamellar space and interact with the lattice water and ammonium ions in the interlayers via hydrogen bonds (Figure 2, Table 2). The adjacent layers separated by $12.467(6) \AA$, are connected together via these multiple hydrogen bonds.

The asymmetric unit of 2 consists of one crystallographically independent ytterbium(III) ion, a PMIDA ${ }^{4-}$ anion, and an ammonium ion for charge balance (Figure 4). The $\mathrm{Yb}$ (III) ion is coordinated by a polydentate PMIDA anion in a tetradentate fashion via one oxygen atom from each of the carboxylates (O5 and O6), one oxygen atom from the phosphonate (O1), and a nitrogen atom from the amino group (N1). This forms three five-membered chelation rings similar to the lanthanum compound, 1. Three other PMIDA anions coordinating through two phosphonate oxygen atoms $(02 \mathrm{~A}$ and $03 \mathrm{~A})$ and one carboxylate oxygen atom (04B) completes the coordination number of seven around the central $\mathrm{Yb}$ (III) ion. Interestingly, the two carboxylate
Table 2 | Hydrogen bonds for compounds $\mathbf{1}$ and 2.

\begin{tabular}{|c|c|c|c|}
\hline D-H...A & $(\mathrm{D}-\mathrm{H}-\mathrm{A}) \mathrm{/}^{\mathrm{O}}$ & $d(D \ldots A) / A ̊$ & Symmetry operation \\
\hline \multicolumn{4}{|c|}{ COMPOUND 1} \\
\hline $\mathrm{N} 2-\mathrm{H} 2-\mathrm{O} 7$ & 152.54 & $2.820(16)$ & $1+x, y, z$ \\
\hline N2-H3-O5 & 163.65 & $2.825(15)$ & $x, y, z$ \\
\hline N2-H4-O10 & 168.50 & $2.962(14)$ & $x, y, z$ \\
\hline O10-H10A-O4 & 114.58 & $2.919(16)$ & $x, y, 1+z$ \\
\hline O8-H8A-O6 & 122.54 & $2.656(14)$ & $1-x, 2-y, 2-z$ \\
\hline \multicolumn{4}{|l|}{ COMPOUND 2} \\
\hline $\mathrm{N} 2-\mathrm{H} 2 \mathrm{C}-\mathrm{O} 7$ & 167.14 & $2.794(5)$ & $-1+x, y, z$ \\
\hline $\mathrm{N} 2-\mathrm{H} 2 \mathrm{D}-\mathrm{O} 6$ & 150.82 & $3.032(4)$ & $1-x, 1 / 2+y, 1 / 2-z$ \\
\hline N2-H2E-O5 & 120.46 & $3.069(5)$ & $1-x,-1 / 2+y, 1 / 2-z$ \\
\hline $\mathrm{N} 2-\mathrm{H} 2 \mathrm{~F}-\mathrm{O} 3$ & 170.86 & $2.855(6)$ & $1-x, 1-y, 1-z$ \\
\hline
\end{tabular}

groups in $\mathrm{PMIDA}^{4-}$ adopt different coordination modes. One carboxylate group is only coordinated to $\mathrm{Yb}$ atom by $\mathrm{O} 6$ in a monodentate fashion, while the other is bidentate bridging through $\mathrm{O} 4$ and $\mathrm{O5}$. The geometry about the central metal ion is a capped trigonal prism $\mathrm{YbO}_{6} \mathrm{~N}$. The $\mathrm{Yb}-\mathrm{O}$ distances are in the range 


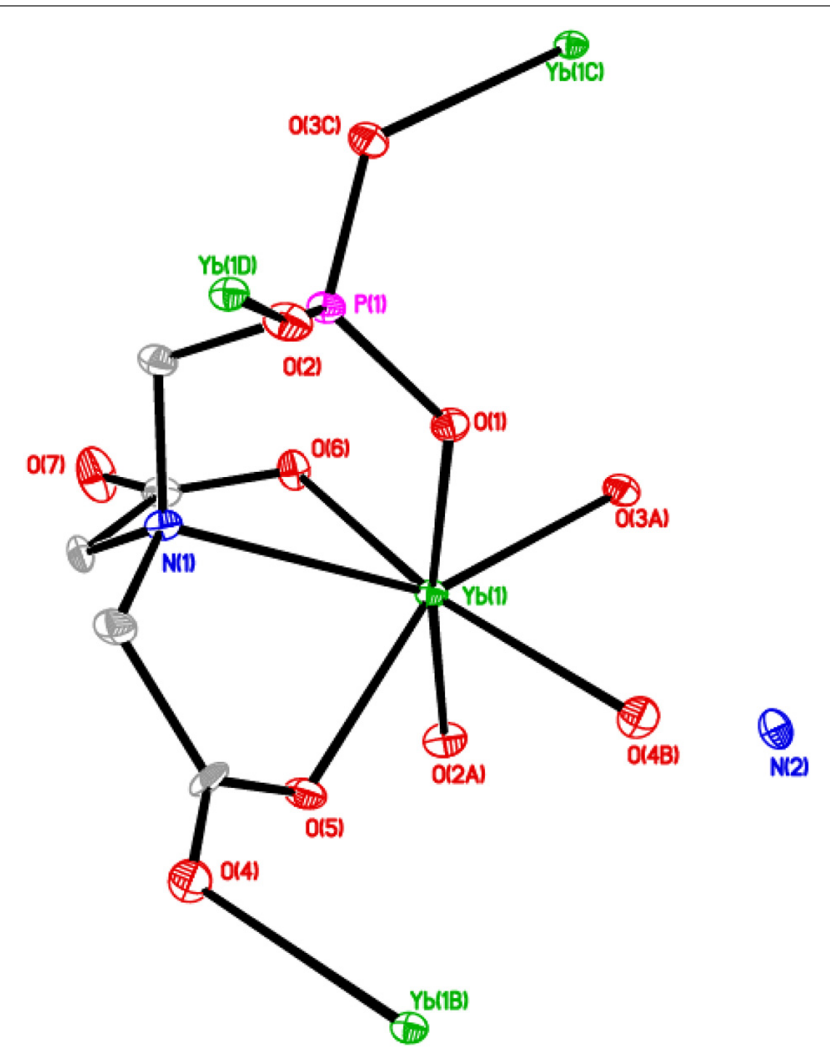

FIGURE 4 | ORTEP plot of 2 showing the labeling scheme. The thermal ellipsoids are drawn at the $50 \%$ probability level. Symmetry codes for the generated atoms: (a) $x, 0.5-y,-0.5+z$; (b) $1-x,-y, 1-z$; (c) $1-x, 1-y, 1-z$; (d) $x, 0.5-y, 0.5-z$.

2.174(3)-2.318(3) $\AA$, while the Yb-N distance is 2.576(5) $\AA$ and are comparable with those reported for similar compounds in the literature (Zabicky, 1970; Burwell and Thompson, 1991a,b; Tang et al., 2006a). The $\mathrm{Yb}$ (PMIDA) chelating units are connected by alternating bridging carboxylate and phosphonate groups along the [010] direction, forming chains with a corrugated pattern. The phosphonate oxygen $\mathrm{O} 2$, bridges the chains together along the [001] direction to build the layered material as shown in Figure 5.

The PMIDA ${ }^{4-}$ anion is a heptadentate ligand, coordinating through three phosphonate oxygen atoms $(\mathrm{O} 1, \mathrm{O} 2, \mathrm{O} 3)$, three carboxylate oxygen atoms (O4, O5, and O6) and the amino nitrogen (N1). The phosphonate group is tridentate and bridges with three equivalent $\mathrm{Yb}$ (PMIDA) chelating units, that is the three oxygen atoms of the $\mathrm{PO}_{3}$ group are bonded to different ytterbium atoms, such that each is directly connected to only one ytterbium atom in a [111] connectivity (Massiot et al., 1997; Bauer et al., 2006; Tang et al., 2006a,b; Zhou et al., 2010). Both the Yb(III) and phosphonate group are 3-connectors in terms of topology giving the 2D layer a vertex symbol of 6 (Ayi et al., 2013), with two types of four-coordinate nodes. This kind of topology has also been observed in similar lanthanide(III) complexes, but with two types of three-coordinate nodes (Massiot et al., 1997; Bauer et al., 2006; Tang et al., 2006a,b; Zhou et al., 2010). The non-coordinating carboxylate oxygen $\mathrm{O}(7)$ points into the interlamellar space and interacts with the ammonium ions through hydrogen bonding (Table 2). The interlayer distance is 9.181(3) A. Hydrogen bonding between the ammonium ions and the layers hold the layers together.

It is interesting to note that whereas the two reactions took place in aqueous solution, compound $\mathbf{1}$ has coordinated and lattice water, while compound $\mathbf{2}$ is an anhydrous complex. There is a change in coordination number from 9 in compound 1-7 in compound 2 attributed to the decrease in the size in going from $\mathrm{La}^{3+}(103 \mathrm{pm})$ to $\mathrm{Yb}^{3+}(87 \mathrm{pm})$ ions (Shannon, 1976; Ma et al., 2007) Similar hydrothermal reactions of $\mathrm{H}_{4}$ PMIDA with lanthanide(III) salts reported by Mao and coworkers gave lanthanide(III) carboxylate-phosphonates, which was formulated as $\mathrm{Ln}(\mathrm{HPMIDA})\left(\mathrm{H}_{2} \mathrm{O}\right)_{2} \cdot \mathrm{H}_{2} \mathrm{O}(\mathrm{Ln}) \mathrm{Gd}, \mathbf{1} ; \mathrm{Tb}$, 2; Dy, 3; Y, 4; Er, 5; Yb, 6; Lu, 7) (Tang et al., 2006a). Their structures feature a three-dimensional network with helical tunnels. In this present investigation, compound $\mathbf{1}$ is formulated as $\left(\mathrm{NH}_{4}\right)\left[\mathrm{La}(\mathrm{PMIDA})\left(\mathrm{H}_{2} \mathrm{O}\right)\right] \bullet \mathrm{H}_{2} \mathrm{O}$ and compound 2 has the formula $\left(\mathrm{NH}_{4}\right)[\mathrm{Yb}(\mathrm{PMIDA}]$, both featuring a two-dimensional structure with extensive hydrogen bonding involving the ammonium ion. In the previously reported compounds, the phosphonate group is singly protonated, whereas the compounds under present study shows complete deprotonation of the acidic oxygen atoms. The complete deprotonation is made possible by the addition of urea into the synthetic media, which resulted in the incorporation of ammonium ion in the present structure.

The infrared spectra of the compounds are particularly informative, providing supporting evidence for the structural differences existing between compounds 1 and 2 . The free ligand shows absorption peaks in the spectral range between 1731 and $1216 \mathrm{~cm}^{-1}$ arising from stretching and bending vibrational modes associated with $\mathrm{C}=\mathrm{O}, \mathrm{C}-\mathrm{O}$, and $\mathrm{C}-\mathrm{H}$ bonds. While the band at $1731 \mathrm{~cm}^{-1}$ is assigned to $v_{\text {asym }}(\mathrm{C}=\mathrm{O})$, the one at $1473 \mathrm{~cm}^{-1}$ is due to $v_{\text {sym }}(\mathrm{C}=\mathrm{O})$. The bands at $1336,1265,1244$, and $1216 \mathrm{~cm}^{-1}$ are attributed to $v_{s}(\mathrm{C}-\mathrm{O})$ whereas those at 1442 and $1423 \mathrm{~cm}^{-1}$ are due to $\delta\left(\mathrm{C}-\mathrm{H}\right.$ in $\left.-\mathrm{CH}_{2}-\right)$. In the infrared spectrum of 1 , the broad band in the spectral region $3500-3360 \mathrm{~cm}^{-1}$ (peaking at ca. $3436 \mathrm{~cm}^{-1}$ ) is attributed to the $v(\mathrm{O}-\mathrm{H})$ of water molecules involved in hydrogen bonds. This feature is absent in compound 2. The broad absorption bands observed at ca. $3207 \mathrm{~cm}^{-1}$ (1) and at ca. $3180 \mathrm{~cm}^{-1}$ (2) are attributed to the $v_{s}(\mathrm{~N}-\mathrm{H})$ vibrations involved in hydrogen bonding. The stretching mode of $-\mathrm{CH}_{2}$ groups is markedly visible in the spectra, giving rise to peak around $2981 \mathrm{~cm}^{-1}$ in 1 and $2948 \mathrm{~cm}^{-1}$ in 2 . The strong peaks observed at 1558 and $1399 \mathrm{~cm}^{-1}$ in 1 (1593, and $1384 \mathrm{~cm}^{-1}$ in 2 ) are due to the asymmetric and symmetric stretching mode of the $\mathrm{CO}_{2}^{-}$bonds of the carboxyl group. This is lower than the $1731 \mathrm{~cm}^{-1}$ absorption peak seen in that of the free ligand. This down field shift in the absorption frequency is a clear indication that the carboxylate groups are involved in coordinating to the metal center (Zabicky, 1970; Nakamato, 1978; Deacon and Phillips, 1980; Burwell and Thompson, 1991a,b; Drumel et al., 1995; Ayi et al., 2011) in both $\mathbf{1}$ and 2. In the infrared spectrum of 2 , the characteristic antisymmetric and symmetric stretching bands for the carboxylate ions are present with the corresponding $\Delta\left[v_{\text {assym }}\left(\mathrm{CO}_{2}^{-}\right)-v_{\text {sym }}\left(\mathrm{CO}_{2}^{-}\right)\right]$values being 188 


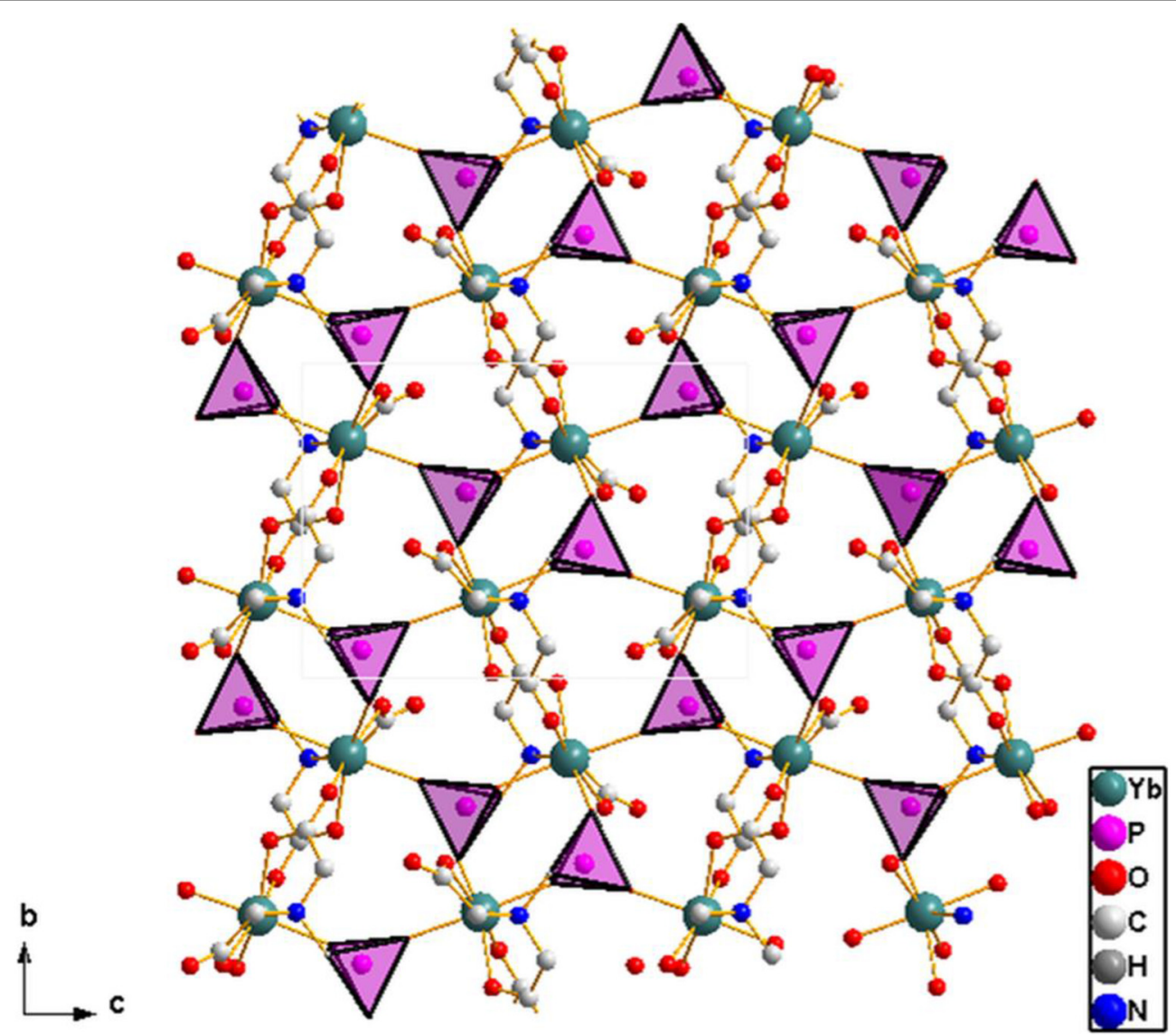

FIGURE 5 | Structure of 2 viewed along [100] direction showing the connectivity that gives the 2D layer. Note the phosphonate group [111] connectivity mode. Ammonium ions are ommitted for clarity.

and $209 \mathrm{~cm}^{-1}$ indicating the presence of carboxylate groups in the anti-unidentate and bridging- $\eta^{2}$-anti,anti-chelate coordination modes, respectively (Nakamato, 1978; Deacon and Phillips, 1980; Drumel et al., 1995). The vibrational modes of the phosphonate $\left(\mathrm{PO}_{3}\right)$ units are also noticeable in the infrared spectra of compounds 1 and 2 . In $\mathbf{1}$, the assymmetric stretching vibrational band of $\mathrm{P}-\mathrm{O}$ group is observed at $1018 \mathrm{~cm}^{-1}$ and at $1084 \mathrm{~cm}^{-1}$ for 2, while the symmetric stretching mode is at $981 \mathrm{~cm}^{-1}$ in 1 and at $1020 \mathrm{~cm}^{-1}$ in 2 . The P-C stretching modes are obsereved around $787 \mathrm{~cm}^{-1}$ in both compounds.

In order to investigate the thermal stability of these materials, the TGA curves of compounds 1 and 2 were measured (Figure 6). Compound 1, releases the interlayer water molecule of crystallization in the temperature range $62-197^{\circ} \mathrm{C}$. The observed weight loss of $4.62 \%$ is close to the calculated value $(4.35 \%)$. In the region $202-376^{\circ} \mathrm{C}$, there is a weight loss of $8.92 \%$ (calc. $8.84 \%$ ) attributed to the loss of coordinated water molecule and $\mathrm{NH}_{3}$, as well as a loss of about $11.50 \%$ due to the presence of little impurities in the bulk sample. However, the final weight loss of $42.29 \%$ (calc. $43.78 \%$ ) corresponds to the decomposition of the organic part of the material to give $\mathrm{LaPO}_{4}$ (JCPDF card no. 01-084-0600) as the final product. Compound 2 is thermally stable up to $300^{\circ} \mathrm{C}$. The first weight loss of $28.82 \%$ (calc. $28.25 \%$ ) is attributed to the loss of $\mathrm{NH}_{3}, 2 \mathrm{CO}$, and $\mathrm{CO}_{2}$. A plateau

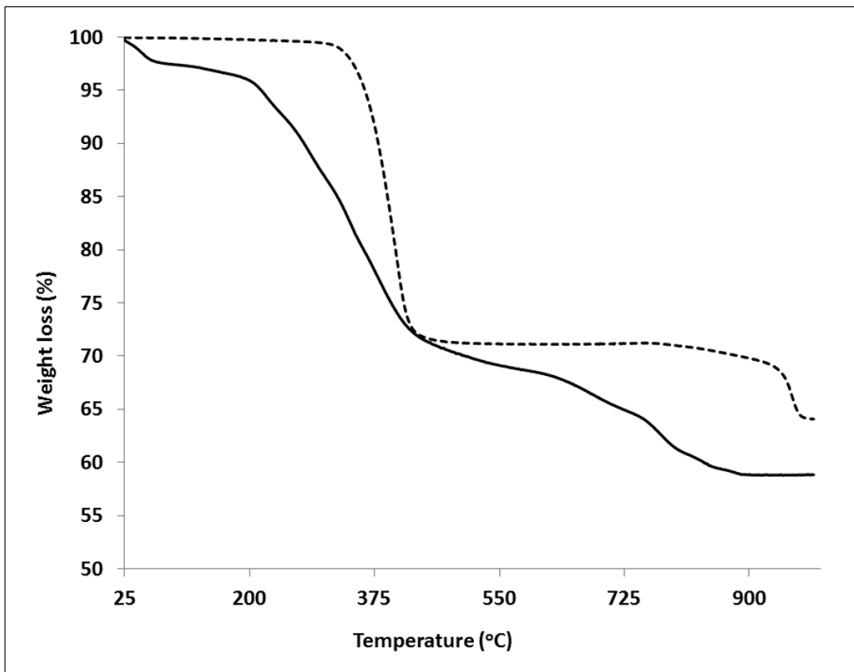

FIGURE 6 | TGA curves of compounds 1 (solid) and 2 (dashed).

appears in the range $422-849^{\circ} \mathrm{C}$, above which a final weight loss of $35.9 \%$ (calc. $35.28 \%$ ) occurs, corresponding to the decomposition of the organic part to give $\mathrm{YbPO}_{4}$ (JCPDF card no. 01-076-1643). 


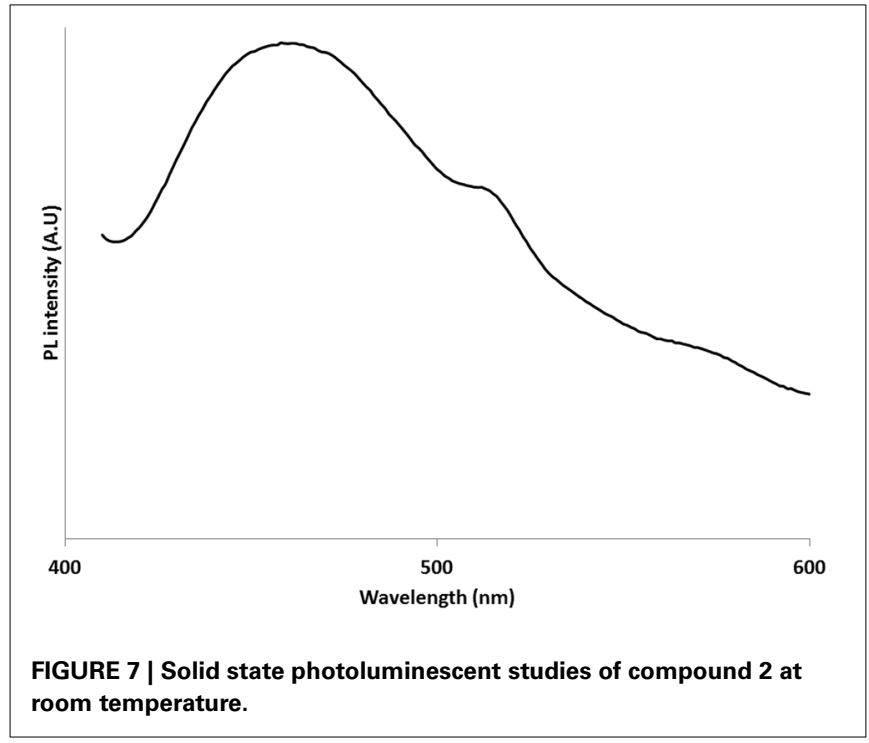

The photoluminecence properties of compound 2 was investigated in the solid state at room temperature (Figure 7). Under excitation of $330 \mathrm{~nm}$, the compound shows a broad emission band at $\lambda_{\max }=460 \mathrm{~nm}$, This emission is essentially in the blue luminescent region, which corresponds to ligand centered fluorescence (Tang et al., 2006a; Zhou et al., 2010). Owing to the quenching effect of the luminiscent state reported for complexes with coordinated water molecules, (Song et al., 2004; Sarkar et al., 2006; Deng et al., 2011) the solid state luminescence of 1 was not studied.

\section{CONCLUSION}

We have successfully synthesized hydrothermally, two new compounds based on $\mathrm{N}$-(phosphonomethyl)iminodiacetic acid $\left(\mathrm{H}_{4} \mathrm{PMIDA}\right)$, namely $\left(\mathrm{NH}_{4} \mathrm{La}(\mathrm{PMIDA})\left(\mathrm{H}_{2} \mathrm{O}\right) \bullet \mathrm{H}_{2} \mathrm{O}, \mathbf{1}\right.$, and $\left(\mathrm{NH}_{4}\right) \mathrm{Yb}(\mathrm{PMIDA}), 2$. The presence of the ammonium ions serves to compensate the framework negative charge in both compounds and is crucial in the syntheses of the compounds under investigation as it stabilizes the structures through hydrogen bonding interactions. The change in the coordination number from 9 for compound 1-7 for compound 2 clearly shows that the size of the cation plays an important role in determining the coordination number. Thus, ion with larger radius favors a higher coordination number and a larger cavity to accommodate more water molecules (Shannon, 1976; Ma et al., 2007). Solid state photoluminescent studies of compound 2 at room temperature shows broad emission in the blue luminiscent region, which is essentially attributed to ligand centered fluorescence. Efforts are under way to synthesize the complete series of the ammonium ion-templated lanthanide(III) complexes with this particular ligand with a view to elucidate their crystal structures, magnetic and luminescent properties.

\section{ACKNOWLEDGMENTS}

Ayi A. Ayi is grateful to the Fulbright Commission for the award of a Fellowship and to the University of Calabar for granting research leave. The kind assistance of Jon Burns, Augustin Diaz, and Brian Mosby is highly appreciated. We thank the R. A. Welch Foundation for partial supports under Grant No. A-0673.

\section{SUPPLEMENTARY MATERIAL}

The Supplementary Material for this article can be found online at: http://www.frontiersin.org/journal/10.3389/fchem. 2014.00094/abstract

Supporting Information Available: X-ray crystallographic files in CIF format (CCDC 847459) and (CCDC 847460) for compounds $\mathbf{1}$ and $\mathbf{2}$, respectively) as well as simulated and experimental XRD powder patterns for compounds $\mathbf{1}$ and $\mathbf{2}$.

\section{REFERENCES}

Almeida Paz, F. A., Shi, F.-N., Klinowski, J., Rocha, J., and Trindade, T. (2004). Synthesis and characterization of the first three-dimensional mixed-metal center inorganic organic hybrid framework with N(phosphonomethyl)iminodiacetate. Eur. J. Inorg. Chem. 2759-2768. doi: 10.1002/ejic. 200400005

Ananias, D., Paz, F. A. A., Carlos, L. D., Geraldes, C., and Rocha, J. (2006). Optical detection of solid-state chiral structures with unpolarized light and in the absence of external fields. Angew. Chem.-Int. Ed. 45, 7938-7942. doi: 10.1002/anie.200602849

Ayi, A. A., Burrows, A. D., Mahon, M. F., and Sebestyen, V. M. (2013). A molybdenum diphosphonate network structure exhibiting reversible dehydration and selective uptake of methanol. Cryst. Eng. Comm. 15, 9301-9303. doi: $10.1039 / \mathrm{c} 3 \mathrm{ce} 40484 \mathrm{f}$

Ayi, A. A., Kinnibrugh, T. L., and Clearfield, A. (2011).Linear chain aluminium(III) carboxymethylphosphonate with encapsulated ammonium ions. Dalton Trans. 40, 12648. doi: 10.1039/c1dt11620g

Bao, S. S., Ma, L. F., Wang, Y., Fang, L., Zhu, C. J., Li, Y. Z., et al. (2007). Anion-directed self-assembly of lanthanide-notp compounds and their fluorescence, magnetic, and catalytic properties. Chem.-Eur. J. 13, 2333-2343. doi: 10.1002/chem.200601097

Bauer, S., Bein, T., and Stock, N., (2006). Inorganic-organic hybrid compounds: synthesis and characterization of three new metal phosphonates with similar characteristic structural features. J. Solid State Chem. 179, 145-155. doi: 10.1016/j.jssc.2005.10.008

Bazaga-García, M., Colodrero, R. M. P., Papadaki, M., Garczarek, P., Zon, J., Olivera-Pastor, P., et al. (2014). Guest molecule-responsive functional calcium phosphonate frameworks for tuned proton conductivity. J. Am. Chem. Soc. 136, 5731-5739. doi: 10.1021/ja500356z

Bruker. (2005).SAINTP+ for NT. Data Reduction and Correction Program v. 7.56. Madison, WI: Bruker AXS.

Burwell, D. A., and Thompson, M. E. (1991a). Synthesis of layered $\mathrm{Zr}\left(\mathrm{O}_{3} \mathrm{PCH}_{2} \mathrm{CH}_{2} \mathrm{COCl}\right)_{2}$ from $\mathrm{Zr}\left(\mathrm{O}_{3} \mathrm{PCH}_{2} \mathrm{CH}_{2} \mathrm{COOH}\right)_{2}$. Chem. Mater. 3, 14. doi: $10.1021 / \mathrm{cm} 00016 \mathrm{a} 030$

Burwell, D. A., and Thompson, M. E. (1991b). Synthesis of amide-and ester functionalized zirconium phosphonates. Chem. Mater. 3, 730. doi: $10.1021 / \mathrm{cm} 00016 \mathrm{a} 030$

Chelebaeva, E., Larionova, J., Guari, Y., Ferreira, R. A. S., Carlos, L. D., Paz, F. A. A., et al. (2008). luminiscent and cyano-bridged $\mathrm{Tb}^{3+}-\mathrm{Mo}^{3+}$ coordination polymer: toward multifunctional materials. Inorg. Chem. 47, 775-777. doi: $10.1021 /$ ic702192k

Clearfield, A. (1988). "Metal Phosphonate Chemistry," in Progress in Inorganic Chemistry Vol. 47, ed K. D. Karlin (New York, NY: John Wiley), 371-510.

Cunha-Silva, L., Lima, S., Ananias, D., Silva, P., Mafra, L., Carlos, L. D., et al. (2009). Multi-functional rare-earth hybrid layered networks: photoluminescence and catalysis studies. J. Mater. Chem. 19, 2618-2632. doi: 10.1039/b817381h

Cunha-Silva, L., Mafra, L., Ananias, D., Carlos, L. D., Rocha, J., and Paz, F. A. A. (2007). Phospholuminiscent lanthanide-organic 2D networks: a combined synchronton powder X-ray diffraction and solid state NMR study. Chem. Mat. 19, 3527-3538. doi: 10.1021/cm070596q

Deacon, G. B., and Phillips, R. J. (1980). Relationships between the carbon-oxygen stretching frequencies of carboxylato complexes and the type of carboxylate coordination. Coord. Chem. Rev. 1980, 33, 227-250. doi: 10.1016/S00108545(00)80455-5 
Deng, X.-J., Yu, Q., Zhang, X.-Q., Bian, H.-D., and Liang, H. (2011).Synthesis and crystal structures of two homo- and heteronuclear 1D nanochain coordination polymers connected from $\mathrm{Zn}$ (II)/Co(II) with N-Phosphonomethyl-1, 3thiazolidine-4-carboxylic acid ligand. Transit. Met Chem. 36, 157-161. doi: 10.1007/s11243-010-9448-9

Drumel J. P., Barboux, P., Bujoli-Doeuff, M., and Bujoli, B. (1995). Synthesis, structure and reactivity of some functionalized zinc and copper(II) phosphonates. Inorg. Chem. 34, 148-156. doi: 10.1021/ic00105a026

Evans, O. R., Ngo, H. L., and Lin, W.-B. (2001). Chiral porous solids based on lamellar lanthanide phosphonates. J. Am. Chem. Soc. 123, 10395. doi: $10.1021 /$ ja0163772

Ferreira, R. A. S., Rocha, J., Trindade, T., Carlos, L. D., and Nogueira, H. I. S. (2008). Photoluminiscent 3D lanthanide organic frameworks with 2, 5pyridinedicarboxylic and 1, 4-phenylenediacetic acids. Cryst. Growth Des. 8, 2505-2516. doi: 10.1021/cg800153a

Gagnon, K. J., Perry, H. P., and Clearfield, A. (2012). Conventional and unconventional metal_organic frameworks based on phosphonate ligands: MOFs and UMOFs. Chem. Rev. 112, 1034-1054. doi: 10.1021/cr2002257

Galdecka, E., Galdecki, Z., Gawryszewska, P., and Legendziewicz, J. (2000). Structure of a novel polynuclear europium compound with N-phosphonomethylglycine: heptaaquaperchloratodi-mu(4)-Nphosphonomethylglycine-dieuropium(III) triperchlorate monohydrate, $[\mathrm{Eu}-2(\mathrm{HO} 3 \mathrm{PCH} 2 \mathrm{NH} 2 \mathrm{CH} 2 \mathrm{CO} 2)(2)(\mathrm{H} 2 \mathrm{O})(7)(\mathrm{ClO} 4)]$ center dot 3ClO(4)center dot H2O. New J. Chem. 24, 387-391. doi: 10.1039/b000230p

Girginova, P. I., Paz, F. A. A., Soares-Santos, P. C. R., Ferreira, R. A. S., Carlos, L. D., Amaral, V. S., et al. (2007). Synthesis, characterization and luminiscent properties of lanthanide-organic polymer with picolinic an glutaric acid. Eur. J. Inorg. Chem. 2007, 4238-4246. doi: 10.1002/ejic.200601213

Groves, J. A., Stephens, N. F., Wright, P. A., and Lightfoot, P. (2006). Novel openframework architectures in lanthanide phosphonates. Solid State Sci. 8, 397-403. doi: 10.1016/j.solidstatesciences.2006.02.018

Groves, J. A., Wright, P. A., and Lightfoot, P. (2005). Two closely related lanthanum phosphonate frameworks formed by anion-directed linking of inorganic chains. Inorg. Chem. 44, 1736-1739. doi: 10.1021/ic048456v

Gutschke, S. O. H., Price, D. J., Powell, A. K., and Wood, P. T. (1999). Solvothermal synthesis of the canted antiferromagnet $\left\{\mathrm{K}_{2}\left[\mathrm{Co}\left(\mathrm{O}_{3} \mathrm{PCH}_{2} \mathrm{~N}\left(\mathrm{CH}_{2} \mathrm{CO}_{2}\right)_{2}\right]_{6} \cdot \mathrm{xH}_{2} \mathrm{O}\right.\right.$. Angew.Chem.Int. Ed. 38, 1088. doi: 10.1002/(SICI)1521-3773(19990419)38:8<1088::AID-ANIE1088>3.0.CO;2-2

Huang, Y.-L., Huang, M.-Y., Chan, T.-H., Chang, B-C., and Lii, K.-H. (2007). Synthesis, structural characterization and luminiscence properties of lanthanide oxalatophosphonates: $\mathrm{Na}\left[\mathrm{M}_{3}\left(\mathrm{H}_{2} \mathrm{O}\right)_{4}\left(\mathrm{C}_{2} \mathrm{O}_{4}\right)_{4}\left(\mathrm{CH}_{3} \mathrm{PO}_{3}\right)\right] .2 \mathrm{H}_{2} \mathrm{O}(\mathrm{M}=\mathrm{Nd}$ and Pr). Chem. Mater. 19, 3232. doi: 10.1021/cm070602i

Kinnibrugh, T. L., Ayi, A. A., Bahmotov, V., and Clearfield, A. (2013). Probing structural changes in a phosphonate-based metal-organic framework exhibiting reversible dehydration. Cryst. Growth Des. 13, 2973-2981. doi: $10.1021 / \mathrm{cg} 400399 \mathrm{v}$

Legendziewicz, J., Gawryszewska, P., Gazdecka, E., and Gazdecki, Z. (1998). Novel polynuclear compound of europium with $N$-phosphonomethylglycine: spectroscopy and structure. J. Alloys Compd. 275-277, 356-360. doi: 10.1016/S09258388(98)00339-9

Liu, B., Li, B.-L., Li, Y.-Z., Chen, Y., Bao, S.-S., and Zheng, L.-M. (2007). Lanthanide diruthenium (II, III) compounds showing layered and PtS-type open framework structures. Inorg. Chem. 46, 8524. doi: 10.1021/ic0621695

Liu, D., Lu, K., Poon, C., and Lin, W. (2014). Metal-organic frameworks as sensory materials and imaging agents. Inorg. Chem. 53, 1916-1924. doi: $10.1021 /$ ic 402194 c

Lukes, I., Kotek, J., Vojtisek, P., and Hermann, P. (2001). Complexes of tetraazacycles bearing methylphosphinic/phosphonic acid pendant arms with copper(II), zinc(II) and lanthanides(III). a comparison with their acetic acid analogues. Coord. Chem. Rev. 216-217, 287-312. doi: 10.1016/S0010-8545(01)00336-8

Ma, Y.-S., Li, H., Wang, J.-J., Bao, S.-S., Cao, R., Li, Y.-Z., et al. (2007). Threedimensional lanthanide(iii)-copper(ii) compounds based on an unsymmetrical 2-pyridylphosphonate ligand: an experimental and theoretical study. Chem. Eur. J. 13, 4759-4769. doi: 10.1002/chem.200601786

Mao, J.-G. (2007). Structures and luminiscent properties of lanthanide phosphonates. Coord. Chem. Rev. 251:1493. doi: 10.1016/j.ccr.2007.02.008

Mao, J. G., and Clearfield, A. (2002). Metal carboxylate-phosphonate hybrid layered compounds: synthesis and single crystal structures of novel divalent metal complexes with $\mathrm{N}$-(phosphonomethyl)iminodiacetic acid. Inorg. Chem. 41:2319. doi: $10.1021 /$ ic $011094 \mathrm{w}$
Massiot, D., Drumel, S., Janvier, P., Doeuff, M. B., and Bujoli, B. (1997). Relationship between solid state ${ }^{31} \mathrm{P}$ NMR parameters and X-ray structural data in some zinc phosphonates. Chem. Mater. 9:6. doi: 10.1021/cm960417x

Nakamato, K. (1978). Infrared and Raman Spectra of Inorganic and Coordination Compounds. New York, NY: Wiley Interscience.

Paz, F. A. A., and Klinowski, J. (2008). Poly[hexaaquabis $\left(\mu_{3}\right.$-naphthalene2,6-dicarboxylato)( $\mu_{2}$-naphthalene-2,6-dicarboxylato)diholmium(III)]. Acta Cryst. E. 64, M140-M141. doi: 10.1107/S1600536807064483

Paz, F. A. A., and Klinowski, J. (2007). Designing novel organic-inorganic frameworks. Pure Appl. Chem. 79, 1097-1110. doi: 10.1351/pac200779061097

Paz, F. A. A., Rocha, J., Klinowski, J., Trindade, T., Shi, F. N., and Mafra, L. (2005). Optimised hydrothermal synthesis of multi-dimensional hybrid coordination polymers containing flexible organic ligands. Prog. Solid State Chem. 33, 113-125. doi: 10.1016/j.progsolidstchem.2005.11.033

Poojary, D. M., Zhang, B., and Clearfield, A. (1994). Structure of a mixed phosphate/phosphonate layered zirconium compound from synchrotron XRay powder diffraction data. Angew. Chem. Int. Ed. Engl. 33:2324. doi: 10.1002/anie. 199423241

Rodrigues, M. O., da Costa, N. B., de Simone, C. A., Araujo, A. A. S., Brito-Silva, A. M., Paz, F. A. A., et al. (2008). Theoretical and experimental studies of the photoluminescent properties of the coordination polymer $\left[\mathrm{Eu}(\mathrm{DPA})(\mathrm{HDPA})\left(\mathrm{H}_{2} \mathrm{O}\right)_{2}\right] \cdot 4 \mathrm{H}_{2} \mathrm{O}$. J. Phys. Chem. B 112, 4204-4212. doi: 10.1021/jp075047m

Sarkar, M., Banthia, S., and Samantha, A. (2006). A highly selective 'off-on' fluorescence chemosensor for Cr(III). Tetrahedron Lett. 47, 7575-7578. doi: 10.1016/j.tetlet.2006.08.091

Serpaggi, F., and Ferey, G. (1998). Hybrid open frameworks (MIL- $n$ ). Part 6 Hydrothermal synthesis and X-ray powder $a b$ initio structure determination of MIL-11, a series of lanthanide organodiphosphonates with three-dimensional networks, $\mathrm{Ln}^{\mathrm{III}} \mathrm{H}\left[\mathrm{O}_{3} \mathrm{P}\left(\mathrm{CH}_{2}\right)_{n} \mathrm{PO}_{3}\right](n=1-3)$. J. Mater. Chem. 8, 2749-2755. doi: $10.1039 / \mathrm{a} 802715 \mathrm{c}$

Serre, C., Stock, N., Bein, T., and Ferey, G. (2004). Synthesis and characterization of a new three-dimensional lanthanide carboxyphosphonate $\mathrm{Ln}_{4}\left(\mathrm{H}_{2} \mathrm{O}\right)_{7}\left[\mathrm{O}_{2} \mathrm{C}\right.$ $\left.\mathrm{C}_{5} \mathrm{H}_{10} \mathrm{~N}-\mathrm{CH}_{2}-\mathrm{PO}_{3}\right]_{4}\left(\mathrm{H}_{2} \mathrm{O}\right)_{5}$. Inorg. Chem. 43:3159. doi: 10.1021/ ic035363p

Shannon, R. D. (1976). Revised effective ionic radii and systematic studies of interatomic distances in halides and chalcogenides. Acta Crystallogr. A32, 751. doi: 10.1107/S0567739476001551

Sharma, C. V. K., and Clearfield, A. (2000). Macrocyclic leaflets. J. Am. Chem. Soc.122, 1558. doi: 10.1021/ja9938377

Sheldrick, G. M. (2008a). SHELXTL 2008/4, Structure Determination Software Suite. Madison, WI: Bruker AXS.

Sheldrick, G. M. (2008b). SADABS-2008/1, Bruker/Siemens Area Detector Absorption Correction Program. Madison, WI: Bruker AXS.

Shi, F.-N., Almeida Paz, F. A., Girginova, P. I., Amaral, V. S., Rocha, J., Klinowski, J., et al. (2006). Hydrothermal synthesis, structural characterisation and magnetic behaviour of $\left(4,4^{\prime}-\text { bpyH }\right)_{2}\left[\mathrm{M}\left(4,4^{\prime}-\right.\right.$ bpy $\left.)\left(\mathrm{H}_{2} \mathrm{O}\right)_{4}\right]\left[\mathrm{V}_{2} \mathrm{O}_{2}(\text { pmida })_{2}\right] \cdot 2 \mathrm{H}_{2} \mathrm{O}$ $\left(\mathrm{M}=\mathrm{Mn}^{2+}\right.$ and $\left.\mathrm{Co}^{2+}\right)$. Inorg. Chim. Acta 359, 1147-1158. doi: 10.1016/j.ica.2005.10.055

Shi, F.-N., Almeida Paz, F. A., Girginova, P., Mafra, L., Amaral, V. S., Rocha, J., et al. (2005). Hydrothermal synthesis, structural characterisation and magnetic behaviour of hybrid complexes of $\mathrm{N}$-(phosphonomethyl)iminodiacetate. J. Mol. Struct. 754, 51-60. doi: 10.1016/j.molstruc.2005.06.026

Shi, F. N., Cunha-Silva, L., Ferreira, R. A. S., Mafra, L., Trindade, T., Carlos, L. D., et al. (2008). Interconvertable modular framework and layered lanthanide(III)etidronic acid coordination polymers. J. Am. Chem. Soc. 130, 150-167. doi: 10.1021/ja074119k

Soares-Santos, P. C. R., Paz, F. A. A., Ferreira, R. A. S., Klinowski, J., Carlos, L. D., Trindade, T., et al. (2006). Coordination modes of pyridine-carboxylic acid derivatives in samarium(III) complexes. Polyhedron 25, 2471-2482. doi: 10.1016/j.poly.2006.03.002

Song, J. L., Lei, C., and Mao, J. G. (2004). Synthesis, Crystal structures and luminescent properties of novel layered lanthanide sulphonate-phosphonates. Inorg. Chem. 43, 5630-5634. doi: 10.1021/ic049376u

Song, J.-L., and Mao, J.-G. (2005). New types of blue, red or near IR luminiscent phosphonate decorated lanthanide oxalate. Chem. Eur. J. 11:1417. doi: 10.1002/chem.200400889

Tang, S. F., Song, J. L., Li, X. L., and Mao, J. G. (2007). Novel luminiscent lanthanide(iii) diphosphonates with rarely observed topology. Cryst. Growth Des. 7, 360-366. doi: 10.1021/cg060590y 
Tang, S.-F., Song, J.-L., Li, X.-L., and Mao, J.-G. (2006a). Luminiscent lanthanide(III) carboxylate phosphonate with helical tunnels. Cryst. Growth Des. 6, 2322. doi: 10.1021/cg0602481

Tang, S.-F., Song, J.-L., and Mao, J.-G. (2006b). Syntheses, crystal structures and characterizations of a series of new layered lanthanide carboxylate-phosphonates. Eur. J. Inorg. Chem. 2011-2019. doi: 10.1002/ ejic. 200600039

Ying, S. M., and Mao, J. G. (2006). Introducing a second ligand: new route to luminscent lanthanide polyphosphonates. Cryst. Growth Des. 6, 964-968. doi: $10.1021 / \operatorname{cg} 050554 j$

Zabicky, J. (1970). The Chemistry of Amides. London: John Wiley and Sons.

Zhang, B., and Clearfield, A. (1997). Crown ether pillared and functionalized layered zirconium phosphonates:? a new strategy to synthesize novel ion selective materials. J. Am. Chem. Soc. 119:2751.

Zhang, B., Poojary, D. M., and Clearfield, A. (1998). Synthesis and crystal structure of the linear chain Zirconium Organophosphonates $\left(\mathrm{NH}_{4}\right) \mathrm{ZrF}_{2}\left[\mathrm{H}_{3}\left\{\mathrm{O}_{3} \mathrm{PCH}_{2} \mathrm{NH}\left(\mathrm{CH}_{2} \mathrm{CO}_{2}\right\}_{2}\right)\right]$. Inorg. Chem. 37:249.

Zhang, B., Poojary, D. M., Clearfield, A., and Peng, G.-Z. (1996). Synthesis, characterization and amine intercalation behaviour of zirconium $\mathrm{N}$-(phosphonomethyl)iminodiacetic acid layered compounds. Chem. Mater. 8:1333.
Zhou, T.-H., Yi, F.-Y., Li, P.-X., and Mao, J.-G. (2010).Synthesis, Crystal structures and luminiscent properties of two series of new lanthanide(III) aminocarboxylate-phosphonates Inorg. Chem. 49, 905-915. doi: 10.1021/ic90 1621x

Conflict of Interest Statement: The authors declare that the research was conducted in the absence of any commercial or financial relationships that could be construed as a potential conflict of interest.

Received: 01 August 2014; paper pending published: 22 August 2014; accepted: 08 October 2014; published online: 05 November 2014.

Citation: Ayi AA, Kinnibrugh TL and Clearfield A (2014) Hydrothermal synthesis and structural characterization of ammonium ion-templated lanthanide(III) carboxylatephosphonates. Front. Chem. 2:94. doi: 10.3389/fchem.2014.00094

This article was submitted to Inorganic Chemistry, a section of the journal Frontiers in Chemistry.

Copyright (c) 2014 Ayi, Kinnibrugh and Clearfield. This is an open-access article distributed under the terms of the Creative Commons Attribution License (CC BY). The use, distribution or reproduction in other forums is permitted, provided the original author(s) or licensor are credited and that the original publication in this journal is cited, in accordance with accepted academic practice. No use, distribution or reproduction is permitted which does not comply with these terms. 